\title{
TEACHING THE THEORY AND SKILLS OF LEGAL ETHICS TO SOUTH AFRICAN LLB STUDENTS
}

\author{
E Snyman-Van Deventer \\ Bluris LLB LLM LLM LLD \\ Professor, Department of Mercantile Law \\ University of the Free State \\ CF (Neels) Swanepoel \\ $B A$ LLB LLM LLD \\ Professor, Department of Public Law \\ University of the Free State
}

\section{SUMMARY}

Stakeholders in South African legal education have been clear on the need for a legal ethics module as part of the LLB degree programme. In this contribution, the authors draw on relevant literature, particularly regarding the American experience, as well as their own observations as legal practitioners and lecturers to advance the conceptualization, design and presentation of such a potential fully-fledged legal ethics module (or modules). Some reflections on the conceptual points of departure for a legal ethics module are followed by a discussion of the more pragmatic aspects associated with legal ethics teaching, namely the goals and objectives pursued (the "what and why") and the methods used (the "where, when and how"). The article argues that although a stand-alone module is urgently needed, legal ethics need not be taught in isolation, but should ideally be incorporated throughout the curriculum using a mixed-method approach. Such an approach will inculcate in students the realization that ethical issues are not restricted to a lecture or a set of notes: Ethics whether based on students' personal moral values and philosophy, or the professional and disciplinary rules and codes of conduct of the legal profession - are and will remain an integral part of their everyday and future working lives.

"We should not only introduce concepts of ethics and professionalism in class, but we should make these concepts a pervasive theme of our curriculum and pedagogy."

\section{INTRODUCTION}

From a recent legal ethics summit held in Durban under the auspices of the South African Law Society, ${ }^{2}$ to an insightful article on the issue of legal

Weresh "Fostering a Respect for our Students, our Specialty, and the Legal Profession: Introducing Ethics and Professionalism into the Legal Writing Curriculum" 2006 21(2) Touro LR 427427 . 
ethics as part of the LLB curriculum, published on LitNet Academic, ${ }^{3}$ roleplayers and stakeholders in South African legal education have been stating it unequivocally: A legal ethics module must be introduced as part of the South African LLB degree programme as soon as possible. At the ethics summit in Durban, working groups were asked to answer various questions, including: What should we be teaching with regard to ethics at LLB and professional level? They reported as follows: ${ }^{4}$

"A full module in philosophy/legal ethics needs to be introduced to allow students to engage with these issues. If possible, and ideally, an ethical component should be built into every module of the LLB programme. General ethics and ethical philosophies need to be integrated into LLB modules."

The ethics report on the summit also reflects Rycroft's recommendations on the possible establishment of a Law Society website where law lecturers would be able to obtain learning material on legal ethics. ${ }^{5}$

This article is therefore aimed at contributing to the conceptualization, content and presentation of a potential fully-fledged legal ethics module (or, as we will suggest, more than one module) as part of the South African LLB degree programme. The article is also partly informed by our own experience in practice, and as lecturers at a South African university that has been presenting legal ethics as part of a first-year module since 1999. The sentiment expressed throughout this research is that legal ethics as a module need not be taught in isolation, but that there are numerous options for incorporating ethics elements into many traditional theoretical subjects that form part of the LLB degree programme. This contribution starts off by reflecting on the conceptual point of departure for a module in legal ethics, which Van Wyk ${ }^{6}$ believes is located in a well-considered "normative framework". The conceptualization of a legal ethics module is then followed by a particular emphasis on the pragmatic design of such a module, with specific reference to the American experience. First, however, the concept of legal ethics requires clarification.

\section{DEFINING LEGAL ETHICS}

Kirchner explains that "[l]egal ethics in the wider sense of the term have the same function for the practice of law that the International Humanitarian Law

2 Law Society of South Africa (LSSA) Report on Ethics Summit Report on Summit on Professional Legal Ethics, Durban, (February 2014) 1-15 (hereinafter "LSSA Report on Ethics Summit').

3 Van Wyk "Regsetiek as Deel van die LLB Kurrikulum" 2014 11(1) LitNet Academic 1-26 http://www.litnet.co.za/Article/regsetiek-as-deel-van-die-llb-kurrikulum (accessed 2014-0527).

LSSA Report on Ethics Summit 13.

5 LSSA Report on Ethics Summit 15.

2014 11(1) LitNet Academic 3.

For an in-depth discussion of the definition of legal ethics, see Elkins "A Conversation Called Ethics" 198610 Legal Studies Forum 265-273. 
(IHL) has for the soldier's work: That is to civilize the way in which we 'fight'." Legal ethics in the narrow sense is a set of ethical rules. ${ }^{9}$

According to Kelly, legal ethics has four distinct meanings, namely (i) the professional rules of protocol, such as rules pertaining to trust funds, etcetera ${ }^{10}$ (ii) the relevant principles and appropriate modes of conduct established through analysis of cases and opinions on ethical matters by, for example, bar association committees, ${ }^{11}$ (iii) criticism of the law and society for failing to meet standards of justice, ${ }^{12}$ and (iv) the practical scenario where a lawyer makes decisions on how to handle his or her client, inter alia based on principles of personal morality. ${ }^{13}$

Burns describes legal ethics teaching as teaching students to understand the legal profession, its structures, its roles and responsibilities, the roles and responsibilities of the lawyer in providing professional service, the student's own values and attitudes, as well as the disciplinary rules of the legal profession. ${ }^{14}$ To her, legal ethics is also about examining personal values and moralities, as well as issues such as the legitimacy of requiring a lawyer to do something in conflict with his or her own personal values. ${ }^{15}$

In Henriss-Anderssen's view, legal ethics is "the study of the values underpinning the legal system, and the role of the lawyer in that system, including: professional rules, and personal values". ${ }^{16}$ She believes ethical standards and professional responsibility thus involve (i) understanding the institutions of law, its processes and structures, (ii) understanding the values underlying the legal system, (iii) understanding the role of the lawyer in the legal system, (iv) considering the relationship between the roles of the lawyer, the legal system and justice, (v) understanding broader notions of justice, (vi) the personal and professional values of individual lawyers, (vii) developing moral competence, and (viii) being able to exercise ethical judgments.

In this article, we use the term "legal ethics" in both a narrow and broad sense, with reference to professional and disciplinary rules and codes of conduct, as well as morality, values and philosophy. For purposes of this contribution, the terms "legal ethics", "legal responsibility", "professionalism" and "professional responsibility" are used more or less interchangeably.

8 Kirchner "Legal Ethics Education in Germany" 20152 Indonesian Journal of International and Comparative Law 98104.

9 Kirchner 20152 Indonesian Journal of International and Comparative Law 112.

10 Kelly "Notes on the Teaching of Ethics in Law School" 19805 Journal of the Legal Profession 2121.

Ibid.

12 Kelly 19805 Journal of the Legal Profession 22.

3 Kelly 19805 Journal of the Legal Profession 23.

14 Burns “Teaching Legal Ethics” 1993 4(1) Legal Education Review 141141.

15 Ibid.

16 Henriss-Anderssen "Teaching Legal Ethics to First Year Law Students" 2002 13(1) Legal Education Review 4547.

17 Henriss-Anderssen 2002 13(1) Legal Education Review 47-48. 


\section{CONCEPTUALIZING A LEGAL ETHICS MODULE}

When law faculties start conceptualizing a legal ethics module, which is of course intertwined with the recurricularization of the LLB degree programme, the following needs to be considered:

\section{A normative framework}

Already in the first paragraph of what may very well be the most comprehensive textbook on legal ethics in South Africa, ${ }^{18}$ Lewis writes that "ethical philosophy" does not form part of his book. He adds that it is irrelevant whether any of the "broad ethical principles" in his book have been derived from Plato or whomever else; the book is about the ethical principles recognized by society, particularly by members of the legal profession, which include members of the judiciary. The seminal work then goes on to provide a breakdown of the more general framework within which the teaching of legal ethics may occur as part of the traditional subject content of law programmes, and is quite obviously aimed at practising attorneys. ${ }^{19}$

But, when developing an ethics module, should we be as quick as Lewis to discount a philosophical-ethical framework for the course? With reference to a legal ethics module for university, Van Wyk remarks as follows: ${ }^{20}$

"This contribution deals with the moral crisis currently experienced in the legal profession and the fact that neither current legislation nor rules and codes of conduct seem to succeed in ensuring ethical conduct. One of the reasons probably is that conduct is not based on a well-considered normative value system, but that a purely legalistic approach is deemed sufficient."

She emphasizes that a well-considered normative framework instead of mere compliance with rules should serve as point of departure for a legal ethics module in the LLB degree programme. We support this view: The only way for us to lay the foundation for the development of better equipped, more ethical, law graduates in an extremely diverse South African society in general and student community in particular is to unequivocally and unanimously buy into a normative value system. But where shall we find this ideal normative South African value system? At the Durban summit, a proposal was made for the initiation of a national debate, where ethical issues can be discussed across professional boundaries. ${ }^{21}$ Although we believe this proposal has merit, we would argue that the hosting of a national summit on morality in the broader South African society, drawing its

18 Lewis Legal Ethics: A Guide to Professional Conduct for South African Attorneys (1982) 1.

19 A good example of subject content for teaching legal ethics and professional conduct is presented in De Klerk et al Clinical Law in South Africa 2ed (2006) 29-54. Traditionally, the ethics course presented by the attorneys' profession for purposes of professional development, as well as the module designed by our own faculty, deals with: (i) an introduction to key concepts and terms, such as "fit and proper", "honesty", "integrity", etc, (ii) an introduction to the South African legal profession, (iii) resources, (iv) the legal rules with regard to the legal practitioner's various professional relations, including with the State, the Court, the client, the opposing legal practitioner, as well as the organized profession, (v) pro bono obligations and community involvement, and (vi) etiquette rules.

20 Van Wyk 2014 11(1) LitNet Academic 3; own translation.

21 LSSA Report on Ethics Summit 14. 
participants from the civil service, civil organizations as well as the general public, including schools and churches, is even more important. Nevertheless, the point is this: When conceptualizing a legal ethics module for incorporation into the LLB degree programme, the relevant faculties will have to decide how much attention should be focused on (i) the fairly extensive regulatory framework for professional conduct among jurists in South Africa, and (ii) the broad normative framework as a possible point of departure to instil in students an understanding of the reasons why a jurist is (or should be) exposed to a strong normative value system. The student must be enabled to internalize a particular value system before moving on to study the regulatory framework governing the legal professions in South Africa. Looking at the subject content of our faculty's philosophy-of-law modules, it is not difficult to see the value in possibly linking this to a new legal ethics module as part of the LLB degree programme. ${ }^{22}$ When faculties design a legal ethics module, they should consult their individual departments or lecturers of philosophy of law, or "jurisprudence", as it is called at our institution, in order to (i) achieve optimal integration of the two modules if the faculty decides to continue with both, but also to (ii) facilitate synchronization, and (iii) eliminate any unnecessary overlap between the two. ${ }^{23}$

In such a potential reassessment of existing philosophy-of-law or jurisprudence modules, we believe Van Wyk's proposals ${ }^{24}$ regarding the utilization of Betham's utilitarian theory, Kant's deontology and Aristotle's virtue ethics may prove very useful to achieve integration ${ }^{25}$ between a jurisprudence module and a legal ethics module. However, we would suggest that the conceptualization and design of a legal-ethics module for the LLB degree programme should have "South African constitutionalism" as its foundation and normative framework. "South African constitutionalism" also resonates well with the typically South African and African value system of Ubuntu, which law students may find easier to internalize. In our view, therefore, this improves the chances of acceptance and internalization by law students, which would in turn lead to increased personal and professional moral responsibility. In this regard, the court in the matter of City of Johannesburg Metropolitan Municipality v Blue Moonlight Properties 39 (Pty) $L t d^{26}$ stated the following:

22 To our minds, the question as to whether the graduates we produce are supposed to be experts in the mechanics or the theory of law has not been adequately answered - neither locally nor even overseas. We concede that the answer to this question is in no way a simple one, but would argue that the solution is probably to be found in increasingly trying to strike a balance in the LLB degree curriculum between the theory of law and acquiring legal skills. Eg, see Swanepoel and Bezuidenhout "Integrating Theory and Practice in the LLB Curriculum: Some Reflections" 2008 Special Edition Journal for Juridical Science 99-111; Bezuidenhout The Symbiotic Integration of Theory and Practice: A Sui Generis Approach (Unpublished LLM dissertation, University of the Free State (2009)).

23 The content of the modules offered in our faculty includes aspects closely related to legal ethics, such as the law and the internationalization of human rights, the law and religion, the law and the ideological substructure of justice, the ideological content of the law, the ideological approaches to justice, etc.

24 Van Wyk 2014 11(1) LitNet Academic 7-10.

25 Authors' own emphasis.

262012 (2) SA 104 (CC) 38. 
"The spirit of Ubuntu, part of the deep cultural heritage of the majority of the population, suffuses the whole constitutional order. It combines individual rights with a communitarian philosophy. It is a unifying motif of the Bill of Rights, which is nothing if not a structured, institutionalised and operational declaration in our evolving new society of the need for human interdependence, respect and concern."

Our argument in favour of South African constitutionalism as the normative framework for a university module in legal ethics as a compulsory part of the LLB degree programme is fleshed out and further supported below. The ultimate aim is to help design the subject content for a legalethics module as part of the LLB degree programme, the primary outcome of which is to produce law graduates with an increased moral consciousness. Although such a module should ideally be taught in the third or fourth year of law studies, it may be preceded by a foundational phase in the first year of study, which is discussed next.

\section{Foundational phase of a legal-ethics module}

As the backdrop for the conceptualization of a legal-ethics module for incorporation into the LLB degree programme, the context within which both the law student and the jurist are expected to behave ethically and professionally needs to be considered. The various components comprising this should collectively be related to the values entrenched in the South African Constitution, as discussed in detail below.

\section{Ethical and legal-professional responsibilities of the law student}

At our institution, first-year law students are expected to take an oath in support of a student code of ethics. ${ }^{27}$ This occurs annually in August after it has been dealt with in lectures as part of a legal-practice module. Usually, the event takes the form of a prominent and stately affair on the faculty's year calendar, preferably featuring a guest speaker from the legal fraternity, who addresses students on the topic of legal ethics. The code of ethics is primarily based on the International Bar Association code first adopted in 1956, which was subsequently amended in 1988 to its current format. ${ }^{28}$ The principal academic and professional learning outcomes of the oath-taking may be formulated as follows, and must obviously be dealt with in class as part of the foundational module before the law student takes the oath:

(i) A commitment to the South African Constitution and upholding the rule of law as a law student, citizen and later also legal practitioner in South Africa. In introducing students to South African constitutionalism and the rule of law, it is important to emphasize the anomaly that the South

27 University of the Free State "Student Code of Ethics" in Faculty of Law Baccalaureus Degrees $2015 \mathrm{http} / / /$ apps.ufs.ac.za/dl/yearbooks/243_yearbook_eng.pdf (accessed 201405-30) 4

28 International Bar Association International Code of Ethics www.ibanet.org/Document/ Default.aspx?DocumentUid=A9AB05AA-8B69-4BF2-B52C-97E1CF774AB (accessed 201405-30). 
African Constitution actually came about as a result of a struggle against the previous legal order, and its failure to implement the very core values that now, through a process of negotiations and consensus between all in the country, form the cornerstone of the post-apartheid constitutional State.

(ii) A general commitment to adhere to University/Faculty and professional prescripts on conduct, which necessarily includes abiding by disciplinary codes, as well as the taking of disciplinary steps if these are violated. From the outset, law students need to be sensitized to the fact that mere academic knowledge and skills are not sufficient to be admitted to the legal profession. Something more is required of students to make them "fit and proper" to follow the profession. In this regard, the work of Bobbert, ${ }^{29}$ Du Plessis ${ }^{30}$ and Slabbert ${ }^{31}$ may be used to good effect. However, the legal-professional responsibilities should not be communicated in isolation as being applicable "in a few years" only, but should be taught in the present context of law students' responsibility during their studies. Here, a sound understanding of concepts such as plagiarism, bad behavioural patterns, dishonesty, etcetera, is important to illustrate the correlation between the obligations and attributes of the law student and the future jurist.

(iii) Identifying with and internalizing the socio-economic as well as the constitutional context within which "law" (and thus justice) is practised in South Africa. The aforementioned student code of ethics used at our institution currently fails to address this commitment, and should be amended accordingly. For example, the following undertaking contained in the Law Society of South Africa's code of ethics, adopted in 2006, seems to capture the fundamentals in this regard fairly well: ${ }^{32}$

"All legal practitioners shall -

[c]onduct themselves with courtesy and respect towards participants in proceedings, especially persons without legal representation, so as to ensure compliance with the rules and procedures for the fair conduct of such proceedings; ..."

The abovementioned ethical duty does of course also have certain implications for the Anglo-Saxon accusatory legal process followed in South Africa, where the "winning motive" is emphasized at all costs, and not necessarily the need to see justice prevail. Whether as part of a legal ethics or another LLB module, law students should buy into the following sentiments expressed by Govender: ${ }^{33}$

"I tell attorneys that the day you come back from court and win a bad case, you should hang your head in shame because you have done something that

29 "Die Prokureur se Verantwoordelikheid in sy Prokureurspraktyk" 1993308 De Rebus 658 658-659; "Die Prokureurspraktyk en die Grondwet" 1995327 De Rebus 176 176-177; "Die Prokuraat is 'n Professie" 2001404 De Rebus 15 15-16; "Professionele Onafhanklikheid, Openbare Belang en die Transportbesorger" 1988105 South African LJ 740 740-762.

30 Die Professionele Gedrag van die Juris (1982) 1.

31 "The Requirement of being a 'Fit and Proper' Person for the Legal Profession" 2011 14(4) Potchefstroom Electronic LJ 209/351 209/351-231/351.

32 Manyati-Jele "Can Ethics be Taught?" 2014540 De Rebus 88.

33 Manyati-Jele 2014540 De Rebus 8. 
I believe violates the Constitution and Bill of Rights. We must practise law within a State on the basis of what is fair and just and never try to take advantage of the poor, the small firms, [or] those who cannot afford to run cases like the State can."

Law lecturers would be well advised also to note the work of Kruuse. ${ }^{34}$ In her study, she illustrates the value of "experiential learning" for students by providing them with a scenario that deals with the non-disclosure of documents that may be prejudicial to the legal practitioner's case. This issue of civil procedure is then used as a point of departure to help law students internalize the legal-ethical aspects of such conduct. This is another example of how legal-ethical principles may be covered in an LLB subject other than a legal ethics or jurisprudence module.

In this respect, students should also be introduced to the "utilitarian function" of "law". After all, for years now, it has been stated that the legal profession is also a "service profession". ${ }^{35}$ This should be contextualized for the law student if we are to succeed in instilling a greater sense of morality and professional conduct in our graduates. This also ties in with "responsible citizenship", which contrasts the broader or collective interest with selfrighteousness and avarice. An undertaking by law students in a code of legal ethics may for example read as follows:

"As a law student, I undertake to alleviate the plight of the underprivileged and never behave towards others in a way that is contrary to the virtues of respect, dignity and compassion during my studies or while participating or acting in curricular and extracurricular programmes and activities."

(iv) A commitment to conduct that will be deemed "fit and proper" for admission to the legal professions. Apart from the academic and legalprofessional requirements for admission to the South African legal professions, the person is also expected to prove that (s)he is indeed fit and suitable to enter the field. Precisely what is meant by "fit and proper" does not seem to be defined anywhere, except that it is generally accepted that a person must display integrity, reliability and honesty, being those characteristics that may have the largest impact on the future legal practitioner's legal-professional relations with his/her client, the public and the State, among others. ${ }^{36}$ Slabbert ${ }^{37}$ goes to great lengths to show how the courts interpret "fit and proper" as part of their discretionary powers, and to illustrate that the granting of these discretionary powers to our courts, has the blessing of the Constitutional Court. What is important from a legal-educational perspective is that, from the very start, law students should be made aware of their legalprofessional relations at university level already, including their relationship with their lecturer, their fellow students, their residence and

34 "Substantive Second-level Reasoning and Experiential Learning in Legal Ethics" 20122 Stellenbosch LR280 280 et seq.

35 Bobbert 2001404 De Rebus 15. The six characteristics of the legal profession identified by Bobbert were later applied in judgment in the matter of Die Prokureursorde van die OranjeVrystaat v Schoeman 1977 (4) SA 588 (O).

36 Slabbert 2011 14(4) Potchefstroom Electronic LJ 212/351.

372011 14(4) Potchefstroom Electronic LJ 213/351-216/351. 
university community as well as the public, who indirectly help secure the privilege of studying by paying taxes.

\section{The moral crisis}

A foundational-phase ethics module should not shy away from pointing out to students the current moral crisis experienced in South Africa in general and the legal profession in particular. As far as we know, very little research has been done to determine the possible causes of the moral degeneration in the South African society and, more specifically, the legal profession, even though we believe it is essential for it to be addressed in a philosophy/jurisprudence- or advanced ethics module. At the ethics summit in Durban, Mr Madoda Nxumalo, a practising attorney, spoke about the South African moral crisis against the backdrop of the political and socioeconomic transformation in the country. ${ }^{38}$ His statements do shed some light on the reasons for the onset of moral degeneration in the legal profession. According to him, prior to 1994, previously-disadvantaged attorneys were under the illusion that they would be able "to eat pie in the sky" once the country was democratized:

"When the reality struck home that the more things change, the more they stay the same, attorneys, like all spheres of our society, tripped over each other to attain personal aggrandizement at the expense of ethics. The legal profession and I have no doubt most professions, were so engrossed in transformation and inadvertently neglected ethics."

He went on to describe a reality we are but all too familiar with in the attorney's profession in South Africa: ${ }^{40}$

"We are prepared to hire previously disadvantaged practitioners in order to fulfil quotas and score cards, all under the pretext of economic empowerment ... Recently, an in thing is to swallow smaller firms, who happen to be Black, by larger firms but only to attract contracts. There is nothing wrong with it as long as such hiring and merging are equally beneficial to both players. The problem only arises when there are sinister undertones. Once we invoked such mischievous thoughts, then we have ethical issues. Some of us view transformation as a threat to our wealth and we are prepared to protect it even if it means defying ethics."

With respect, we find it difficult to follow certain aspects of this argument, and we are not referring to the equal benefits that members of the "new" firm should receive. If this speaker sees nothing wrong with mergers between previously advantaged and smaller, previously disadvantaged firms in order to secure contracts, it is not clear what the so-called "mischievous thoughts" could be other than attempts to attract business. Our remarks are not meant to criticize the speaker, but rather to emphasize the complexity of the South African reality, as well as to illustrate the challenges in dealing with and solving legal-ethical problems in the country. Moral issues in the broader African context are equally complex and require more research. For instance, echoing Van Wyk's argument that a sustainable moral frame of

\footnotetext{
Manyati-Jele 2014540 De Rebus 10.

Ibid.

Ibid.
} 
reference depends on the adoption of a common normative framework, Aja remarks as follows: ${ }^{41}$

"Such common understandings, in the field of ethical systems, are the only lasting foundation upon which a modern Africa can be built."

With reference to the moral framework of the Nigerian lgbo tribe, which even varies within the tribe itself, Aja makes a strong argument for the need to find "fundamental uniformity", despite what he calls "cultural relativity". ${ }^{42}$ $\mathrm{He}$ also refers to the various perspectives on the foundations of morality, of which the theological school of thought is but one. The South African media recently reported on the country's chief justice's strong plea for people to turn to religion to find answers to the moral-degeneration problem in South Africa. ${ }^{43}$ It falls outside the scope of this article, and is in any event impossible, to analyse the reasons for the general moral decay in South Africa. We mention this simply to illustrate the urgent need for a national summit to deliberate on the foundations for a uniform South African normative framework to establish sound morality and ethical conduct. However, like the chief justice, ${ }^{44}$ we believe that the truly sustainable normative framework for legal-professional ethics is located in the Constitution of South Africa, which enables South Africans to use fundamental rights that help shape morality, such as freedom of religion, to make morality a lived reality in the country.

Next, we shall argue that there is no shortage of context-based learning material for an ethics module in South Africa, and that the wealth of material at our disposal should be utilized in teaching legal ethics.

\section{Drawing on the South African reality to find learning material}

South Africans have the dubious "privilege" of witnessing regular, almost daily, reports of corruption, fraud and immoral, extravagant behaviour in the public and private sphere of society, including unprofessional conduct by members of the legal profession. To a certain extent, we have developed an immunity of some sorts; nothing can shock us anymore. Van Wyk ${ }^{45}$ provides a detailed description of this moral decay, inter alia the degeneration witnessed in the legal profession. In our view, legal ethics modules should not try to evade this topic in the lecture hall, but should identify and discuss these incidents openly (though also objectively, as one would expect of jurists). Lecturers who seek subject content for legal ethics as far as the extent of the moral crisis in South Africa is concerned, need not look any further than Legal Brief and De Rebus's monthly "Risk Alert" bulletin. The academic term for teaching through the study of real-life case studies is

41 Aja "Changing Moral Values in Africa: An Essay in Ethical Relativism" 1997 31(4) Journal of Value Inquiry 531531.

42 Aja 1997 31(4) Journal of Value Inquiry 532.

43 Evans "Mogoeng Attempts to Clarify Religion Statements" 4 June 2014 Mail \& Guardian http://mg.co.za/article/2014-06-04 (accessed 2014-06-07).

44 lbid.

452014 11(1) LitNet Academic 4 et seq. 
"context-based education", which offers significant added academic outcomes:

"Context helps students understand what they are learning, provides anchor points so they can recall what they learn, and shows them how to transfer what they learn in the classroom to lawyers' tasks in practice."

\section{Legal costs}

If legal costs are not properly covered with law students as part of another course ${ }^{47}$ it is essential for this to be done in a legal-ethics module, either as part of a foundational-phase or advanced course in legal ethics. Where faculties do not have sufficient internal competence, this should be outsourced to expert legal practitioners. For example, if a section of the law of contracts in the existing LLB module does not address the South African Contingency Fees Act and the attorney-client contract that may arise from it, it should be addressed in the ethics module. Legal Brief ${ }^{8}$ contained an article about a law firm who relied on the Contingency Fees Act to charge their client a $25 \%$ "success fee" in the process of facilitating payout on her behalf of two insurance policies that had been taken out on her late husband's life. Payout of these policies was not disputed at any stage, and the law firm only had to do some administrative work - at most, this involved a few letters. For that, the client was charged R150 000 in legal fees "in terms of the Contingency Fees Act". One instinctively wonders whether this conduct was the result of ignorance or avarice.

The proposals above are intended to hopefully help steer and guide the conceptualization of the subject content of a legal-ethics module. Of course, many more legal-ethical aspects may be included in the content of such a module, including - as mentioned - the essence and significance of the legal practitioner's professional relations.

However, so far, we have suggested that the normative point of departure for a legal ethics module, or even an independent module, should be South African constitutionalism, which we shall now discuss in more detail in the following section. The aim is clear: A sufficiently large portion of the citizenry should truly buy into and believe that our supreme law is morally just. In a diverse society such as South Africa, this is an enormous challenge. Therefore, it is particularly important for law students - who will eventually serve as "officials of the court" and thus also "servants of justice" - to fully understand what this means.

\footnotetext{
Stuckey et al Best Practices for Legal Education (2007) 104.

At our institution, this is addressed in a fourth-year subject called "Legal Practice".

48 "'Greedy' Attorney Avoids Being Struck Off" 2 June 2014 http://www.legalbrief.co.za/ article.php (accessed 2014-06-02).
} 


\section{DESIGNING A MODULE ON LEGAL ETHICS, WITH REFERENCE TO THE AMERICAN EXPERIENCE}

The American Bar Association requires all accredited law schools to teach legal ethics. ${ }^{49}$ In light of this requirement, there is a huge volume of work available in the United States (USA) - not only on teaching legal ethics, but also on the subject matter itself. As most of the questions we grapple with have already been debated in the USA ${ }^{50}$ it seems reasonable to draw on especially the American experience in developing and designing a module on legal ethics for the South African LLB student.

\section{Role of academia}

The key question is whether it is the duty of a faculty of law or a law school to teach legal knowledge and skills only, or whether, due to the nature of a university and its greater educational mandate, law faculties are also obligated to teach their students legal ethics. ${ }^{51}$ Faculties of law must be able to teach the rules of professional conduct, but must at the same time have the capacity to assist law students to develop their own moral standard of behaviour, and to make the moral distinction between right and wrong. Moreover, a faculty of law must teach its students the importance of upholding their professional responsibility and ethical standards. ${ }^{52}$ It is the responsibility of law faculties or law schools to "turn out lawyers who know their duties and responsibilities and would abide by them".

Certainly, this burden cannot be carried by faculties or law schools alone. The profession needs to join forces with academia and become involved not only by assisting financially, but also by helping to develop legal-ethics modules and contributing as lecturers. For example, practising attorneys can provide fictional ethical problems, which the lecturer can then use during classroom teaching. The practitioner can even be part of the discussion and invite students to develop their ideas on and solutions to the given problem.

49 ABA Standards and Rules of Procedure for Approval of Law Schools (2015) Standard 303(a)(5). In both the 2014/15 as well as the 2015/16-editions of the ABA Standards and Rules of Procedure for Approval of Law Schools reference is made to "legal ethics" in standard 303(a)(3)(i), namely "(a) A law school shall offer a curriculum that requires each student to satisfactorily complete at least the following ... (3) one or more experiential course(s) totalling at least six credit hours. An experiential course must be a simulation course, a law clinic, or a field placement. To satisfy this requirement, a course must be primarily experiential in nature and must: (i) integrate doctrine, theory, skills, and legal ethics, and engage students in performance of one or more of the professional skills identified in Standard 302". Standard 302 deals with learning outcomes and refers to "ethical responsibilities" and "ethical participation".

50 In as far back as 1908, the ABA adopted a report that included a special recommendation that legal ethics be taught in all law schools in the USA. In the period 1909-1910, 32 law schools taught legal ethics as a regular course, 28 schools had at least lectures in legal ethics, while 60 law schools offered no instruction in legal ethics whatsoever. Anonymous "Teaching Legal Ethics in Law Schools" 1906-1911 2 The American Law School Review 377 377-378.

51 See also Kirchner 20152 Indonesian Journal of International and Comparative Law 107.

52 Ibid.

53 Green "Less is More: Teaching Legal Ethics in Context" 199839 William and Mary LR 357 360 . 
According to Burnham, with ethical questions - just like with substantive questions - we are teaching a process, namely how to answer a question, or rather, how to solve a problem. ${ }^{54}$ With ethical questions, neither student nor lecturer can be neutral or indecisive. There has to be a choice when faced with an ethical question or problem, and "analysis of the ethical principle behind the choice gives the student and the lawyer greater confidence in that choice".55 This view is also expressed by Brooks in respect of the teaching of legal ethics in law schools in New Zealand, namely that the role of law schools along with other providers is to train students "who have the capacity to be able to recognize ethical problems when they arise, the practical know-how to resolve the problems and to avoid to practising unprofessionally, and an attitude to their work which makes ethical practice a daily habit in approaching and resolving dilemmas". ${ }^{56}$

At the University of Michigan Law School, in turn, the three main aims of the teaching of legal ethics or professional liability are as follows:

'[I]ncreasing students' awareness of the practical significance of legal ethics and the relationship between legal ethics and other areas of law; advancing students' appreciation of the complexity of the subject by enriching the philosophical, sociological, historical, and practical dimensions of our legal ethics courses; and inspiring faculty scholarship related to legal ethics, which will, in turn, be brought to bear on teaching students legal ethics."

\section{Goals and methods}

\section{Goals: The "what and why" question}

In the stand-alone legal ethics module, as well as any other module in which a lecturer wishes to include legal ethics teaching, the lecturer must identify the goals and objectives of the module, how to achieve them, and how to assess such achievement. ${ }^{58}$ To Terrell, the curriculum-design process entails the structure, style and technique as well as the substance used to achieve the required outcomes. He does, however, believe that too little emphasis is placed on outcomes. It is more important to determine what we want to teach in a legal ethics module, than how $^{59}$ we wish to teach it. ${ }^{60}$

54 Burnham "Teaching Legal Ethics in Contracts" 199141 Journal of Legal Education 105108.

5 Ibid.

56 Brooks "Ethics and Legal Education" 199828 Victoria University LR 157165.

57 Feldman "Enriching the Legal Ethics Curriculum: From Requirement to Desire" 199558 Law and Contemporary Problems 5151.

58 Burnham 199141 Journal of Legal Education 107; Henriss-Anderssen 2002 13(1) Legal Education Review 49.

59 For the debate on how to teach legal ethics in the USA, e.g. using the problem method, the pervasive method etcetera, also see Morgan "Use of the Problem Method for Teaching Legal Ethics" 199839 William and Mary LR 409 409-419; Burnham 199141 Journal of Legal Education 105-119; Solberg "Reforming the Legal Ethics Curriculum: A Comment on Edward Rubin's 'What's Wrong with Langdell's Method and What to do about it"' 200962 Vanderbilt LR 12-24; Green 199839 William and Mary LR 357-392; Joy "Teaching Ethics in the Criminal Law Course" 200448 Saint Louis University LJ 1239 1239-1248; Kelly 1980 5 Journal of the Legal Profession 21-29.

60 For a discussion on how to teach legal ethics in the South African context, see 422 below. 
We need to ask ourselves why we want a module on legal ethics, and what we want to teach in such a module. We have to decide whether we see the teaching of legal ethics as the teaching of rules of conduct or as something more than that. Green argues that an appropriate goal for a basic module on legal ethics should be "to accomplish as much as possible with limited resources". ${ }^{61}$ This means that we should equip students as best we can "toward becoming lawyers who are conversant with the body of ethical knowledge, skilled at recognizing and resolving ethical dilemmas in light of this knowledge, and familiar with the profession's values". ${ }^{62}$ Students must also be able to develop the necessary skills to identify and recognize ethical problems as they arise in practice, and have the ability or skill to resolve the ethical problem "in light of the history and tradition of legal practice, expressions of professional norms, moral philosophy, and personal morality". ${ }^{3}$ Menkel-Meadow and Sander re-emphasize that the objectives of teaching legal ethics are (i) that students should know how to recognize a legal-ethical issue, even if they cannot immediately solve it, (ii) to instil a sense of individual responsibility, self-regulation, moral and professional questioning, and (iii) to instil a sense of concern for public interest and welfare. ${ }^{64}$ Given their limited resources and time, the lecturer(s) and faculty should decide which aspects and knowledge of legal ethics must be addressed in the legal-ethics module and/or be integrated with the curriculum. ${ }^{65}$

Henriss-Anderssen ${ }^{66}$ agrees that it is necessary to first determine the desired learning outcomes, which is why she emphasizes the use of objectives in curriculum planning. Objectives assist the lecturer to guide, assess and monitor students' learning, and serve as a reference for students themselves to direct and measure their progress. ${ }^{67}$ Henriss-Anderssen divides the objectives into three domains, namely cognitive, affective and skills. ${ }^{68}$ The objectives in the cognitive or intellectual domain refer to, for example, the understanding of the role of law in society, and knowledge of the concepts of justice. ${ }^{69}$ Objectives in the affective (values) domain include enhancement of integrity, and reflection on students' own individual values. ${ }^{70}$ Objectives in the skills domain encompass, amongst others, the ability to recognize and solve ethical problems, and the ability to reflect on the process in doing so.

Robertson lists five curriculum-wide learning objectives for the teaching and learning of legal ethics, namely (i) the social purposes and limitation of a lawyer's role within a legally organized society, (ii) a justification for lawyers'

\footnotetext{
Green 199839 William and Mary LR 367.

62 Ibid. Also see Menkel-Meadow and Sander "The 'Infusion' Method at UCLA: Teaching Ethics Pervasively" 199558 Law and Contemporary Problems 129130.

3 Green 199839 William and Mary LR 367.

4 Menkel-Meadow and Sander 199558 Law and Contemporary Problems 130.

Green 199839 William and Mary LR 367.

2002 13(1) Legal Education Review 49.

Henriss-Anderssen 2002 13(1) Legal Education Review 49.

Henriss-Anderssen 2002 13(1) Legal Education Review 50.

Ibid.

Ibid.

Henriss-Anderssen 2002 13(1) Legal Education Review 51.
} 
work, (iii) the formal legal standards and responsibilities of lawyers, and the contexts in which these standards and responsibilities will apply, (iv) moral responsibility in legal practice through ethical decision-making, and (v) the ability to recognize situations where ethical issues are likely to arise, and to make ethically justifiable decisions in such circumstances. ${ }^{.2}$

The objectives of legal ethics teaching, as viewed by Tzannes, are (i) to teach the rules of professional conduct, (ii) to instil doctrines of ethical practice, and (iii) to enable students to identify various responsibilities with a view to making ethical decisions. ${ }^{73}$

Only once we have established our goal with teaching legal ethics in the South African context, we can determine the method.

\section{Methods: The "where and when" and the "how" question}

\section{(i) The "where and when" question}

Before a decision can be made on any particular teaching methodology, it is necessary to decide whether legal-ethics teaching should be contained in one module only, or should occur in a core module along with inclusion in other substantive modules also, or should take place throughout the entire curriculum, with no specific module dedicated to legal ethics. Put differently, it is necessary to establish whether legal-ethics teaching will occur through pervasive teaching, clinical instruction, simulated practice or a single module ${ }^{74}$ or hopefully a combination of these.

In the process of curriculum design, a key decision to make is whether a particular module will be dedicated to legal ethics. This, however, does not mean that legal ethics teaching cannot or may not take place in other modules also. Legal ethics teaching need not only occur in a module on legal ethics, but can be incorporated throughout the curriculum. In fact, Solberg believes that legal ethics should be integrated throughout most, if not all, modules in the law curriculum, and should not be restricted to one general course on primarily professional responsibility. ${ }^{75}$ It is proposed that in the South African context also, a core module that teaches students the skills and processes to identify and solve ethical questions or problems is indeed crucial, but that this should be enhanced by integrating legal ethics with other core modules also. Burnham uses the example of the law of contract to illustrate the integration of legal ethical questions with a core module, posing to students a number of questions on, for example,

72 Robertson "Providing Ethics Learning Opportunities throughout the Legal Curriculum" 2009 121 Legal Ethics 59.

73 Tzannes "Legal Ethics Teaching and Practice: Are there Missing Elements?" 19971 TM Cooley Journal of Practical and Clinical Law 5966.

74 For a discussion of each of these methods, see Burns 1993 4(1) Legal Education Review 145-151.

75 Solberg 200962 Vanderbilt LR 13; Robertson 200912 Legal Ethics 59-76; Joy 200448 Saint Louis University LJ 1241. 
misrepresenting the negotiating position and purposefully changing of transcriptions. ${ }^{76}$

According to Robertson, "law schools have a responsibility to provide law students with opportunities to engage meaningfully with questions of lawyers' ethical responsibilities throughout their legal studies". ${ }^{77}$ Burns describes the pervasive method as systematically teaching students about legal ethics as relevant issues arise in other substantive law modules, demonstrating to students "that issues in legal ethics pervade all areas of the law and do not arise merely in discrete courses on legal ethics". ${ }^{78}$ The pervasive method, however, can only be successful if adopted by the entire faculty. ${ }^{79}$ Kelly, in turn, believes that the pervasive method would greatly improve the teaching of legal ethics and can supplement or enrich a strong basic course in legal ethics. ${ }^{80}$ This view is shared by Joy, who emphasizes that raising and discussing ethical issues in modules outside the legal ethics modules will increase students' awareness of and sensitivity to ethical issues. It helps develop the skills needed to identify and analyse ethical issues in settings where the focus is not primarily on ethics, as is also the case in the actual practising of law. ${ }^{81}$ In other words, the pervasive teaching of legal ethics will teach students that ethical issues arise throughout practice. $^{82}$

The clinical method is client-centred, requiring students to take responsibility for representing the client as they fulfil the role of lawyer under the supervision of an attorney in an advisory or consultative capacity. ${ }^{83}$ When students are placed in the role of lawyer, it gives them insight into the law governing lawyers and what lawyers do. It further enables them to internalize the application of ethics, applying it to their own conduct also. ${ }^{84}$ Therefore, where students are given the opportunity to gain experience working with clients, they also need to be afforded an opportunity to reflect on and think about the ethics of their dealings with clients and their own ethical conduct. ${ }^{85}$ In addition, by allowing classroom discussions on the ethical and moral questions arising from students' dealings with their clients

76 Burnham 199141 Journal of Legal Education 111-119.

77 Robertson 2009121 Legal Ethics 59.

78 Burns 1993 4(1) Legal Education Review 145. Also see Solberg 200962 Vanderbilt LR 1516; Henriss-Anderssen 2002 13(1) Legal Education Review 53; Menkel-Meadow and Sander 199558 Law and Contemporary Problems 129-138; Link "The Pervasive Method of Teaching Ethics" 198939 Journal of Legal Education 485-489.

Burns 1993 4(1) Legal Education Review 145.

Kolly 19805 Journal of the Legal Profession 27.

81 Joy 200448 Saint Louis University LJ 1240-1241.

82 Pierce "Legal Ethics must be at the heart of the Law School Curriculum" 200226 Journal of the Legal Profession 159161.

83 Burns 1993 4(1) Legal Education Review 145; Venter "Encouraging Personal Responsibility - An Alternative Approach to Teaching Legal Ethics" 199558 Law and Contemporary Problems 287 291. For a discussion on the current status of clinical teaching in South Africa, see Du Plessis "Clinical Legal Education: The Challenge of Large Student Numbers" 2013 38(2) Journal for Juridical Science 17 17-37; Mubangizi and McQuoid-Mason "The Role of University Law Clinics in Public Interest Litigation, with specific reference to South Africa 2013 38(1) Journal for Juridical Science 47-63; Du Plessis and Dass "Defining the Role of the University Law Clinician" 2013 130(2) South African LJ 390 390-406.

84 Moliterno "Experience and Legal Ethical Teaching" 200112 Legal Education Review 37.

85 Kelly 19805 Journal of the Legal Profession 25. 
and cases, all members of the class stand to learn as advice is shared among peers. ${ }^{86}$ Many of the learning opportunities that students receive at law clinics cannot be reproduced outside the clinic. ${ }^{87}$ It is thus argued that this is an essential part of ethical instruction. ${ }^{88}$

Simulated practice is teaching by way of role play in a simulated practice setting and is seen as the best way to overcome problems usually experienced using the clinical method.

The single-course or module method is where legal ethics are taught in a stand-alone module, which needs to include, not only the codes of conduct or professional rules, but also the philosophical and ethical issues that give rise to such codes or rules. ${ }^{90}$ Many view this method as "too little too late".

\section{(ii) Methodologies: The "how" question}

Effective teaching methodologies that provide students with knowledge, analytical reasoning and guided, disciplined experiential learning will help students acquire practical reasoning skills, as well as practical wisdom. ${ }^{92}$ Burns discusses seven methodologies ${ }^{93}$ for teaching legal ethics, namely case studies, ${ }^{94}$ problems,${ }^{95}$ Socratic instruction, ${ }^{96}$ discussions, ${ }^{97}$ video and film presentations, ${ }^{98}$ co-curricular activities ${ }^{99}$ and lectures. ${ }^{100}$ Other methods include the use of social media, such as Facebook, Twitter and Instagram, as well as role play and simulations.

\section{Case studies}

Students can use case studies, which illustrate how a court, tribunal or disciplinary committee dealt with a particular situation, to analyse actual cases of misconduct, allowing them to learn not only about real-life legalethical problems, but also about how to apply the relevant law, codes of conduct or professional rules. ${ }^{101}$ The criticism expressed against this

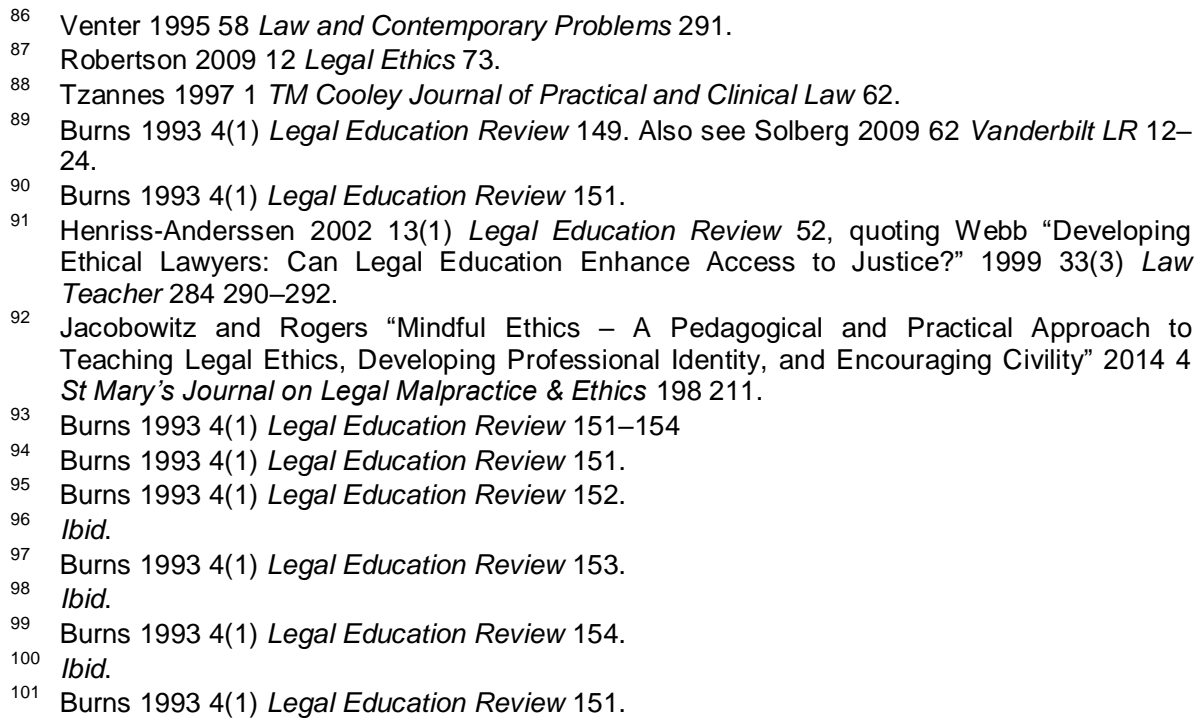


methodology is that case studies do not equip students with the skills to recognize or identify ethical dilemmas as they arise. ${ }^{102}$ Burns describes case studies as a useful secondary source to provide insight in the disciplinary processes and the sanctions that may be imposed for breach of codes of conduct or professional rules. ${ }^{103}$ However, according to Joy, the lecturer should play an active part, exploring the ethical problems in case law with students, as what is emphasized or ignored in class while working through these case studies, will ultimately shape students' perception of the ethical lawyer. ${ }^{104}$ Joy illustrates that case law can be used very effectively if students are guided through the judgment with additional material, and given specific assignments, such as to answer a set of questions on the judgment. The students may then be required to take part in class or smaller group discussions. ${ }^{105}$

\section{Problems ${ }^{106}$}

The problem method hypothetically places the student in the role of the lawyer. ${ }^{107}$ In using the problem method, students are given various plausible hypothetical situations and then, based on the facts, need to identify the issues by using their knowledge of ethical and moral standards and the applicable codes of conduct or professional rules. ${ }^{108}$ As the problem method - unlike case studies - requires students themselves to identify the issues from the facts, this causes them to engage with the facts more intensely. With case studies, the issues have already been identified and dealt with, and are then merely presented to the student, whereas with the problem method, students themselves must determine the ethical issues and find a solution.

\section{Socratic method}

Searching for general, commonly held beliefs and scrutinizing them to determine their consistency with other beliefs, the Socratic method entails a process of hypothesis elimination, finding better hypotheses by steadily identifying and eliminating those that lead to contradictions. Discussions can pertain to decided cases, ethical problems and even hypothetical problems. The "Socratic method" assists in bringing out nuances of a problem that students may not have thought of or assists the student to formulate, possibly for the first time, an ethical stance that the student may adopt. ${ }^{11}$ When using this method, however, students should feel safe and secure to

\footnotetext{
102 Burns 1993 4(1) Legal Education Review 152.

103 Ibid.

104 Joy 200448 Saint Louis University LJ 1243

105 Joy 200448 Saint Louis University LJ 1245.

106 For a detailed discussion of the use of the problem method, see Morgan 199839 William and Mary LR 409-419.

107 Morgan 199839 William and Mary LR 417; Tzannes 19971 TM Cooley Journal of Practical and Clinical Law 62

108 Burns 1993 4(1) Legal Education Review 152; Morgan 199839 William and Mary LR 409.

109 Burns 1993 4(1) Legal Education Review 152

110 Tzannes 19971 TM Cooley Journal of Practical and Clinical Law 63.
} 
engage in a discussion with their lecturer, which may render a smaller group setting more effective. ${ }^{111}$

\section{Discussions}

The discussion method also works best in smaller groups, in which students are given an opportunity to engage personally with ethical and moral dilemmas, thereby developing their cognitive skills. It also teaches students the value of discussion in resolving problems. ${ }^{12}$

\section{Video and film presentations}

Films and videos can trigger ethical issues and problems, and may engage students both emotionally and intellectually, involving them in the discussion of the specific ethical problem that is portrayed. ${ }^{113}$ Video and film presentations not only stimulate interest and attention, but also assist students to more easily grasp concepts through images and the spoken word. Criticism levelled against the use of films and videos is that it may be difficult to find suitable material and may be expensive. ${ }^{114}$ However, a platform such as YouTube offers a number of clips suitable for use in class. According to Rhode, using film and television clips to teach legal ethics builds a foundation for lifelong learning, also offering students the chance to acquire the skill of using popular culture to learn more broadly. However, the use of film and television in class should also include an opportunity for students to reflect on and question the conduct of the fictional character, while at the same time reflecting on their own values. ${ }^{115}$

\section{Co-curricular activities}

Co-curricular activities are learning opportunities that do not form part of the formal curriculum. Participation is voluntary and should primarily be used to reinforce legal-ethical issues already raised, such as in compulsory lectures. ${ }^{116}$ Co-curricular activities may take the form of, inter alia, invited speakers, such as guest lectures by judges or members of the law society; panel discussions with practitioners; meetings of study groups or tutor groups, ${ }^{117}$ and the use of social media. ${ }^{118}$

\section{Lectures}

Being the most cost-effective method to convey knowledge, lectures can and most often do include references to case law. Although they do not require

111 Burns 1993 4(1) Legal Education Review 152.

112 Burns 1993 4(1) Legal Education Review 153.

113 Tzannes 19971 TM Cooley Journal of Practical and Clinical Law 63.

114 Burns 1993 4(1) Legal Education Review 154.

115 Rhode "Legal Ethics: Prime Time and Real Time" 20121 Berkeley Journal of Entertainment and Sports Law 113113.

116 Burns 1993 4(1) Legal Education Review 154

117 Ibid.

118 Hemingway "Keeping it Real: Using Facebook Posts to Teach Professional Responsibility and Professionalism" 201343 New Mexico LR 4356 
any active student involvement nor provide any hands-on experience, lectures can be used to effectively deliver primary information, such as the rules of professional conduct. ${ }^{119}$ Criticism expressed against the lectures method is that it is more suitable for teaching black-letter ethics law, i.e. the applicable rules or codes of conduct. Critics believe lectures do not assist in developing students' understanding of lawyers' personal responsibility for their own actions, nor contribute to enhancing students' analytical abilities. ${ }^{120}$ The lecturer can, however, raise certain ethical problems during a lecture, such as by asking "Could you defend this guilty client?", while lecturing criminal law. ${ }^{121}$

\section{Social media}

As students already use Facebook, blogs and other social media platforms, these serve as a very useful learning tool in that they capture students' attention and awareness. Posts on social media can place emphasis on specific ethical issues to enhance or add to aspects dealt with in, for example, a lecture. Alternatively, social media can be used in a more focused way to deal with specific aspects or issues. Furthermore, social media entries by students or others can be used to teach professional conduct by making students aware of inappropriate or crude language, and teaching them to set limits to what they share. Students must learn that what they post online may affect their professional lives. Actual posts can be used to illustrate ethical dilemmas. ${ }^{122}$ Most often, social media will serve to enhance the problem and discussion methods respectively, by communicating an ethical problem and ensuring student participation in the discussion of the problem.

\section{Role play and simulations}

Using this methodology, students assume the role of the client, the lawyer or even members of disciplinary boards. Role play and simulations do share certain qualities with clinical learning.

Having noted the linkages, overlaps and mutual enhancements between the methodologies described above, it is clear that a mixed-method approach would be the preferred option. By using a combination of methods, students will be exposed to legal ethics and ethical questions and problems in various ways, bringing home to them that ethical issues are not restricted to a lecture, but in fact already form part of their everyday lives and will also be integral throughout their future working lives. The use of various methods also contributes to the development of the diverse skills set required to identify and solve legal ethical problems in various circumstances. It is up to the lecturer to use the most suitable method to best teach the issues, theories or skills needed to fulfil the objectives set.

\footnotetext{
Tzannes 19971 TM Cooley Journal of Practical and Clinical Law 62.

Burns 1993 4(1) Legal Education Review 154.

121 Joy 200448 Saint Louis University LJ 1239-1248.

22 Hemingway 201343 New Mexico LR 43-45.

123 Tzannes 19971 TM Cooley Journal of Practical and Clinical Law 63-64.
} 


\section{$5 \quad$ CONCLUSION}

Everyone, including every legal practitioner, is responsible for his or her own ethical behaviour. ${ }^{124}$ However, law students and every practitioner (through continued legal education) must learn the ethical rules of the legal profession to ensure that their behaviour is in line not only with their own ethical rules, but also with those of the legal profession, and that they fulfil their ethical and professional responsibilities.

In designing a legal ethics module for the South African LLB student, ethics must be seen as more than just legal rules or obligations. It is not only about proper behaviour, but also about responsibility, integrity, honesty and trustworthiness, inspired and guided by personal values, religion, philosophy, as well as professional rules of conduct and codes of ethics. For the South African LLB student, a stand-alone module on legal ethics is indeed crucial. This should, however, be followed by the inclusion or enforcement of legal ethics in other modules also. Burnham phrases the essence of this approach in the form of a question: "What kind of lawyer do I want to be?" ${ }^{125}$ He goes on to explain:

"I believe that we can prepare students to engage in ethical decision making just as we prepare them for other aspects of practice. Because ethical dilemmas pervade the practice of law, ethical questions ought to pervade our teaching. Thus, we must not only teach our students to deal with substantive issues, we must also help them become equally accustomed to resolving ethical questions. Moreover, it is apparent that this inquiry is not only of individual concern but of collective concern, When we ask, "What kind of lawyer do I want to be?" we are also asking what kind of shared legal system we wish to have."

124 Kirchner 20152 Indonesian Journal of International and Comparative Law 120.

125 Burnham 199141 Journal of Legal Education 105.

126 Burnham 199141 Journal of Legal Education 119. 